\title{
Influences of a submerged macrophyte on colony formation and growth of a green alga
}

\author{
J. Dong ${ }^{1,2}$, J. J. Lu ${ }^{1,2}$, G. B. Li ${ }^{1, *}$, L. R. Song ${ }^{1}$ \\ ${ }^{1}$ State Key Laboratory of Freshwater Ecology and Biotechnology, Institute of Hydrobiology, Chinese Academy of Sciences, \\ Wuhan 430072, PR China \\ ${ }^{2}$ University of Chinese Academy of Sciences, Beijing 100039, PR China
}

\begin{abstract}
The effects of the submerged macrophyte Ceratophyllum demersum on the growth and morphology of the green alga Scenedesmus obliquus were assessed by conducting co-culture laboratory experiments $\left(15\right.$ and $25^{\circ} \mathrm{C}$, presence/absence of $3 \mathrm{~g}$ fresh wt of $C$. demersum per litre of water in S. obliquus culture). Growth rate, photosynthetic pigment-based growth, photosynthetic activity and colony formation of $S$. obliquus increased in the presence of $C$. demersum. The proportion of 4 -celled colonies of $S$. obliquus increased from 36 to $76 \%$ at $25^{\circ} \mathrm{C}$, and from 51 to $71 \%$ at $15^{\circ} \mathrm{C}$ in the presence of C. demersum. The induced morphological shift from unicells to colonies in $S$. obliquus promoted sedimentation to the bottom-water region, thereby providing a competitive advantage for the submerged macrophyte.
\end{abstract}

KEY WORDS: Scenedesmus obliquus · Ceratophyllum demersum · Growth · Colony formation · Sedimentation

Resale or republication not permitted without written consent of the publisher

\section{INTRODUCTION}

Numerous clear-water lakes dominated by macrophytes worldwide are shifting to turbid lakes dominated by phytoplankton because of eutrophication (Blindow 1992, Moss et al. 1996, Jeppesen et al. 1997). Submerged plants have important functions in preserving the clear-water state of water ecosystems. One method employed by submerged plants to eliminate competitors (i.e. phytoplankton) is the release of inhibiting compounds. This process is known as allelopathy (Phillips et al. 1978). A great number of allelopathic interactions between macrophytes and phytoplankton have been described (Gross 2003). Macrophytes produce active substances that inhibit phytoplankton photosynthesis (Anthoni et al. 1980) or suppress algal growth, consequently lowering phytoplankton biomass. Plant species that can allelopathically inhibit the growth of cyanobacteria include Myriophyllum spicatum (Gross et al. 1996), Ceratophyllum demersum (Körner \& Nicklisch 2002), Chara spp. (Mulderij et al. 2003) and Elodea spp. (Erhard \& Gross 2006).

Except in the case of nuisance cyanobacterial blooms, green algae, specifically Scenedesmus spp., pose a major threat to ecosystems, and particularly to eutrophic freshwater ecosystems. However, Mulderij et al. (2003) indicated that Chara-filtered water has no allelopathic effects on Scenedesmus obliquus. Jasser (1994) indicated that cyanobacteria are more sensitive to allelochemicals from Ceratophyllum demersum than are green algae, which are unaffected by these allelochemicals. Wu et al. (2011) found that the growth of $S$. obliquus co-cultured with Ceratophyllum demersum was inhibited. Chen (1999) indicated that a Ceratophyllum demersum culture filtrate with low biomass promotes the growth of $S$. obliquus, whereas that with a high concentration inhibits the growth of the algae.

Scenedesmus spp. is commonly found in freshwater ecosystems with diversified ecomorphs (Trainor \& Egan 1991). Previous studies have indicated that high 
total salts (Shubert \& Trainor 1974), low temperature (Siver \& Trainor 1981, Trainor 1992, 1993) and grazers such as Daphnia magna or their filtrates promote Scenedesmus colony formation (Hessen \& Van Donk 1993, Lampert et al. 1994, Lürling \& Van Donk 1996, Lürling 1999, 2003, Von Elert \& Franck 1999, Ha et al. 2004, Verschoor et al. 2004, Yang \& Li 2007). However, to date, only a limited number of studies have investigated the colony formation of Scenedesmus induced by macrophytes. It has been reported that Chara, Elodea, Myriophyllum, and Potamogeton malaianus had no morphological effect on Scenedesmus obliquus (Lürling et al. 2006, Wu et al. 2007), whereas the colony formation of Scenedesmus obliquus has been shown to be induced by submerged Stratiotes aloides (Mulderij et al. 2005b).

The present study attempts to understand the influences of Ceratophyllum demersum on the growth and colony formation of Scenedesmus obliquus.

\section{MATERIALS AND METHODS}

\section{Macrophytes and algae culture}

Scenedesmus obliquus was provided by the Freshwater Algae Culture Collection of the Institute of Hydrobiology, Chinese Academy of Sciences in Wuhan, China. Prior to experimentation, algae were batch-cultured in $2000 \mathrm{ml}$ Erlenmeyer flasks with $1600 \mathrm{ml}$ of BG11 medium (Rippka et al. 1979) at room temperature $\left(25^{\circ} \mathrm{C}\right)$ under a $12 \mathrm{~h}$ light:12 h dark cycle (25 $\mu \mathrm{mol}$ photons $\mathrm{s}^{-1} \mathrm{~m}^{-2}$ ).

Ceratophyllum demersum samples were collected from Dianchi Lake in Yunnan Province, China. Plants were carefully rinsed with tap water to remove adhering epiphytes and zooplankton (Mulderij et al. 2005a, $\mathrm{Wu}$ et al. 2007). The plants were then acclimated in laboratory conditions for 3 mo prior to experimentation.

\section{Experimental design}

The growth and development of Ceratophyllum demersum in natural conditions occurs at temperatures exceeding $15^{\circ} \mathrm{C}$. A temperature of $25^{\circ} \mathrm{C}$ is considered suitable for the plants. Consequently, these 2 temperatures were selected for testing the response of Scenedesmus obliquus to C. demersum.

When it reached an exponential growth phase, Scenedesmus obliquus was cultivated in $250 \mathrm{ml}$ glass flasks filled with $150 \mathrm{ml}$ of fresh BG11 medium under a $12 \mathrm{~h}$ light:12 h dark cycle $\left(25 \mu \mathrm{mol}\right.$ photons $\left.\mathrm{s}^{-1} \mathrm{~m}^{-2}\right)$ at 15 and $25^{\circ} \mathrm{C}$ in the absence (control) or presence of $3 \mathrm{~g}$ fresh weight (FW) of Ceratophyllum demersum per litre of water. The cultivation flasks were covered with parafilm, and each treatment had 3 replicates. Cultures were shaken manually twice a day to maintain cell suspension. Experimentation lasted for 15 d, and regular sampling was conducted every $3 \mathrm{~d}$ on the benchtop to prevent contamination of other cultures.

\section{Growth rate of Scenedesmus obliquus}

Growth rate $(\mu)$ was calculated by the equation

$$
\mu=\left(\ln x_{2}-\ln x_{1}\right) /\left(t_{2}-t_{1}\right)
$$

where $x_{1}$ and $x_{2}$ represent optical density (absorbance at $680 \mathrm{~nm}$ ) at time $t_{1}$ and $t_{2}$, respectively.

\section{Photosynthetic pigments}

The centrifuged cells (12000 rpm, $10 \mathrm{~min}, 4^{\circ} \mathrm{C}$ ) were extracted with $95 \%$ ethanol for $24 \mathrm{~h}$ at $4^{\circ} \mathrm{C}$ in the dark. An Ultrospec 3000 ultraviolet/visible spectrophotometer was used to obtain absorbance readings at 665, 649 and $470 \mathrm{~nm}\left(A_{665}, A_{649}\right.$ and $A_{470}$ respectively) (Lichtenthaler \& Buschmann 2001). Concentrations of chlorophyll a ( $\mathrm{chl}$ a) and carotenoid (both in $\mathrm{mg} \mathrm{l}^{-1}$ ) were calculated as follows:

$$
\begin{aligned}
& \text { Chl a concentration }=13.95 \times A_{665}-6.88 \times A_{649} \\
& \text { Carotenoid concentration }= \\
& \left(1000 \times A_{470}-2.05 \times \text { chl a concentration }\right) / 245
\end{aligned}
$$

\section{Chlorophyll fluorescence}

Chlorophyll fluorescence parameters, such as maximal Photosystem II (PSII) quantum yield $\left(F_{\mathrm{v}} / F_{\mathrm{m}}\right.$, i.e. variable fluorescence divided by maximum fluorescence) and maximum electron transport rate of photosynthesis $\left(\mathrm{ETR}_{\max }\right)$, were measured by Phyto-PAM (Walz). This device can work effectively with very low biomass densities because of its sensitive fluorometric measurements (Körner \& Nicklisch 2002).

\section{Morphology of Scenedesmus obliquus population}

For each replicate, $2 \mathrm{ml}$ samples were fixed with Lugol's fixative and viewed under an inverted microscope at $400 \times$ magnification to count the number of cells per colony (Lürling \& Van Donk 1999). 

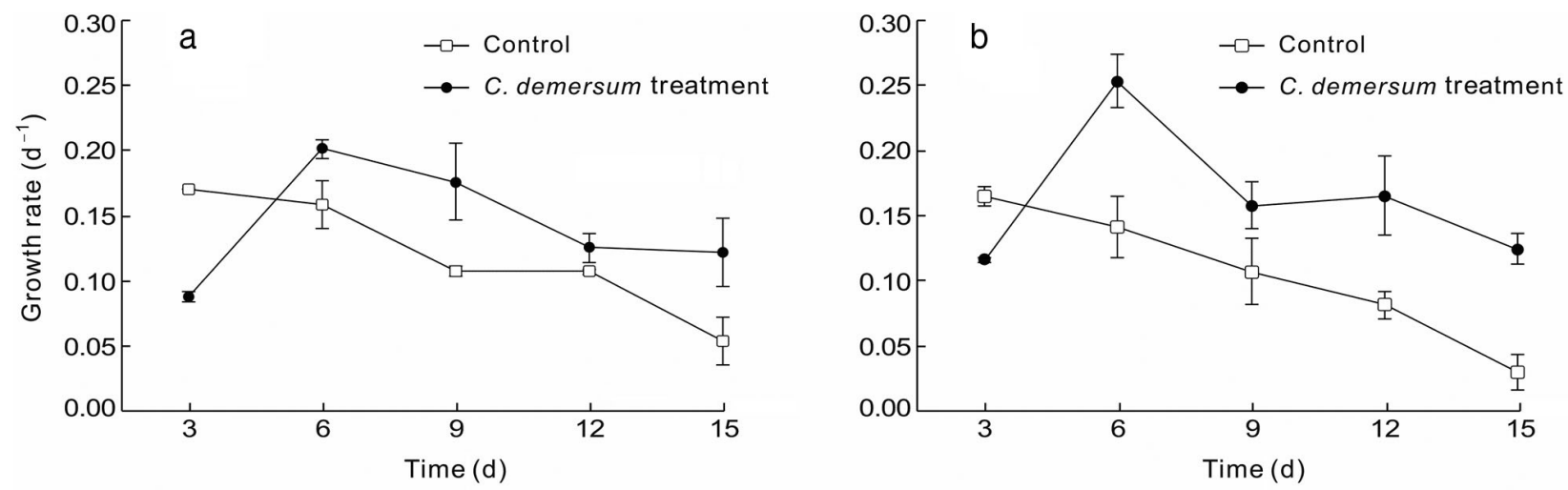

Fig. 1. Growth rate of Scenedesmus obliquus in the absence (control) and presence of Ceratophyllum demersum at (a) $15^{\circ} \mathrm{C}$ and (b) $25^{\circ} \mathrm{C}$

\section{Sedimentation experiments}

At the end of the experiments, $25 \mathrm{ml}$ of algae were sampled from each treatment and placed in a glass column $(25 \times 2 \mathrm{~cm})$ in the dark to initiate sedimentation (Lürling \& Van Donk 2000). Each treatment had 4 replicates. Prior to sedimentation, algae were thoroughly mixed, and the initial algae biomass $\left(C_{0}\right)$ was calculated. After $1 \mathrm{~h}, 2 \mathrm{ml}$ of algae was sampled from the column, and its biomass $\left(C_{1}\right)$ was measured. The sedimentation rate $(r)$ of the algae from the column can be defined according to the SETCOL procedure (Bienfang 1981):

$$
r=\left(C_{1}-C_{0}\right) / C_{1}
$$

\section{Data analysis}

Mean values and standard deviations were calculated for the different replicates $(n=3)$. At the end of the experiments, statistical analysis of the data between the control and Ceratophyllum demersum treatment at 15 and $25^{\circ} \mathrm{C}$ was performed using SPSS 18.0. Two-way ANOVA was used to compare the final growth rate, pigment-based growth, photosynthetic activities, population proportion (unicells and 4-celled coenobia) and sedimentation rate between the control and the $C$. demersum treatment (Lürling \& Van Donk 1999). A value of $\mathrm{p}<0.05$ was considered significant in all analyses.

\section{RESULTS}

\section{Growth of Scenedesmus obliquus}

During the first $3 \mathrm{~d}$, which was considered the lag period, Scenedesmus obliquus in the Ceratophyllum demersum treatment exhibited a slower growth rate compared with the control. However, during the subsequent period, $S$. obliquus in the $C$. demersum treatment exhibited a higher growth rate compared with the control. In the present study, the presence of $C$. demersum promoted the growth of $S$. obliquus (Fig. 1). Two-way ANOVA revealed that $C$. demersum $(p<0.01)$, temperature $(p<0.05)$ and interaction $(\mathrm{p}<0.01)$ had significant effects on the growth rate $\mu$ of $S$. obliquus (Table 1).

\section{Photosynthetic pigment-based growth}

Chl a and carotenoid of Scenedesmus obliquus were higher in the Ceratophyllum demersum treatment at both 15 and $25^{\circ} \mathrm{C}$ than in the control (Fig. 2). At $15^{\circ} \mathrm{C}$, chl a concentration was $6.3 \mathrm{mg} \mathrm{l}^{-1}$ in the control and $10.3 \mathrm{mg} \mathrm{l}^{-1}$ in the C. demersum treatment, and at $25^{\circ} \mathrm{C}$, it was 6.4 and $12.7 \mathrm{mg} \mathrm{l}^{-1}$ respectively. For carotenoid, the concentration was $2.6 \mathrm{mg}$ $\mathrm{l}^{-1}$ in the control and $3.8 \mathrm{mg} \mathrm{l}^{-1}$ in the $C$. demersum treatment at $15^{\circ} \mathrm{C}$, and at $25^{\circ} \mathrm{C}$, it was 2.5 and $4.5 \mathrm{mg}$ $1^{-1}$ respectively. Two-way ANOVA revealed that $C$.

Table 1. Between-subject effects on the dependent variable, Scenedesmus obliquus growth rate $(\mu)$. C. demersum $=$ presence of Ceratophyllum demersum

\begin{tabular}{|lcccrc|}
\hline Source & $\begin{array}{c}\text { SS } \\
\text { (Type III) }\end{array}$ & df & MS & \multicolumn{1}{c|}{$F$} & $\mathrm{p}$ \\
\hline Corrected model & $0.693^{\mathrm{a}}$ & 3 & 0.231 & 104.667 & 0.000 \\
& 6.208 & 1 & 6.208 & 2812.958 & 0.000 \\
Temperature & 0.024 & 1 & 0.024 & 11.011 & 0.011 \\
C. demersum & 0.553 & 1 & 0.553 & 250.767 & 0.000 \\
Temperature $\times$ & 0.115 & 1 & 0.115 & 52.222 & 0.000 \\
$\quad$ C. demersum & & & & & \\
Error & 0.018 & 8 & 0.002 & & \\
Total & 6.918 & 12 & & & \\
Corrected total & 0.711 & 11 & & & \\
${ }^{\mathrm{a}} \mathrm{R}^{2}=0.975$ (adjusted $\left.\mathrm{R}^{2}=0.966\right)$ \\
\multicolumn{7}{l}{} \\
\hline
\end{tabular}



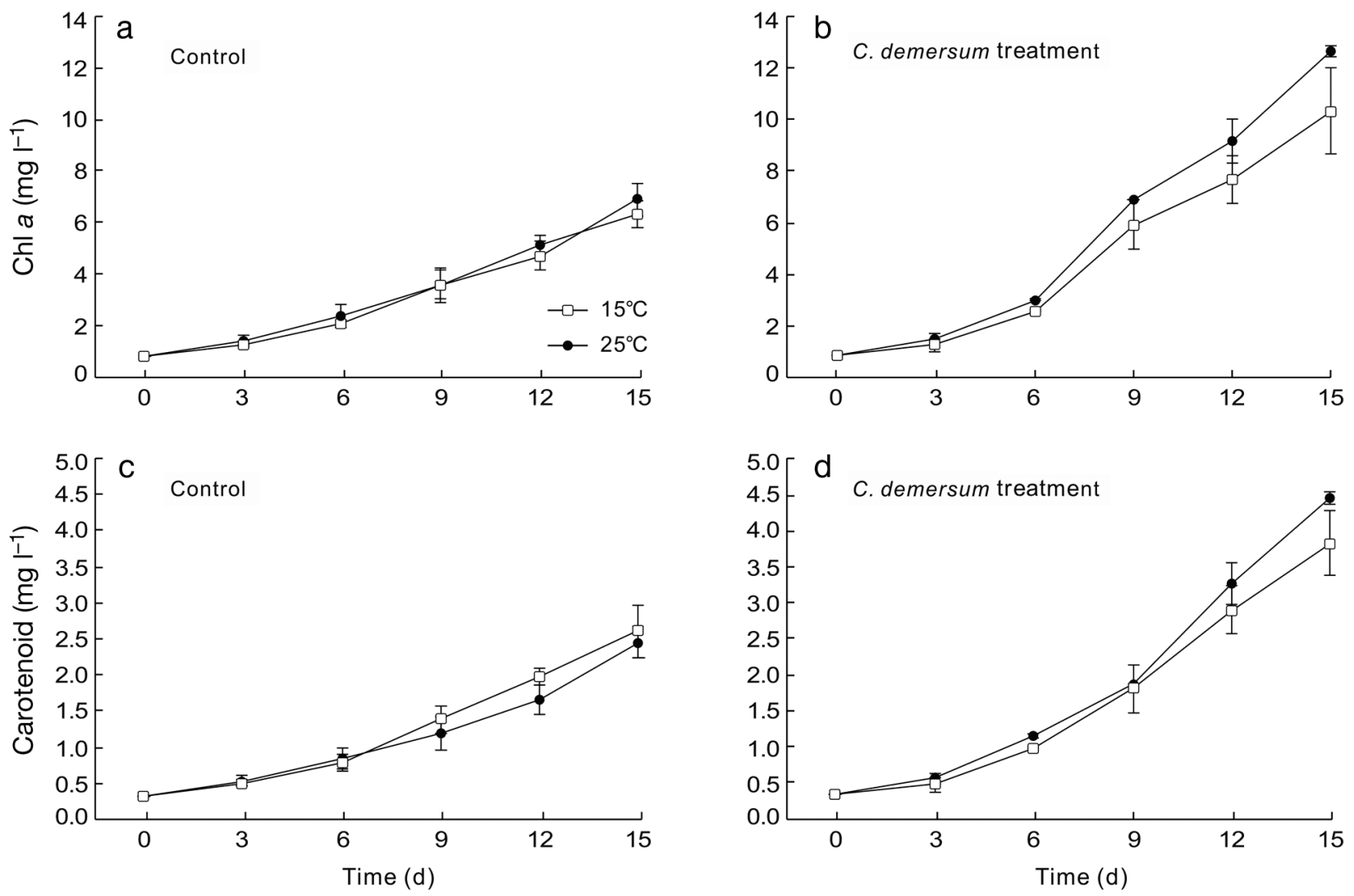

Fig. 2. $(\mathrm{a}, \mathrm{b}) \mathrm{Chl} \mathrm{a}$ and $(\mathrm{c}, \mathrm{d})$ carotenoid concentrations in Scenedesmus obliquus in the absence (control) and presence of Ceratophyllum demersum at 15 and $25^{\circ} \mathrm{C}$

Table 2. Between-subject effects on the dependent variable, chl a concentration in Scenedesmus obliquus. C. demersum = presence of Ceratophyllum demersum

\begin{tabular}{|c|c|c|c|c|c|}
\hline Source & $\begin{array}{c}\text { SS } \\
\text { (Type III) }\end{array}$ & df & MS & $F$ & $\mathrm{p}$ \\
\hline \multirow[t]{2}{*}{ Corrected model } & $187.636^{\mathrm{a}}$ & 3 & 29.212 & 64.040 & 0.000 \\
\hline & 959.076 & 1 & 959.076 & 2102.540 & 0.000 \\
\hline Temperature & 4.346 & 1 & 4.346 & 9.528 & 0.015 \\
\hline C. demersum & 79.496 & 1 & 79.496 & 174.275 & 0.000 \\
\hline $\begin{array}{l}\text { Temperature } \times \\
\text { C. demersum }\end{array}$ & 3.794 & 1 & 3.794 & 8.317 & 0.020 \\
\hline Error & 3.649 & 8 & 0.456 & & \\
\hline Total & 1050.361 & 12 & & & \\
\hline Corrected total & 91.285 & 11 & & & \\
\hline \multicolumn{6}{|c|}{${ }^{\mathrm{a}} \mathrm{R}^{2}=0.960$ (adjusted $\mathrm{R}^{2}=0.945$ ) } \\
\hline
\end{tabular}

demersum presence $(\mathrm{p}<0.01)$, temperature $(\mathrm{p}<$ $0.05)$, and their interaction $(\mathrm{p}<0.05)$ exerted significant effects on the chl a concentration of $S$. obliquus (Table 2). However, the effect of temperature on the carotenoid concentration was not significant $(p>$ 0.05) (Table 3).
Table 3. Between-subject effects on the dependent variable, carotenoid concentration in Scenedesmus obliquus. C. demersum $=$ presence of Ceratophyllum demersum

\begin{tabular}{|c|c|c|c|c|c|}
\hline Source & $\begin{array}{c}\text { SS } \\
\text { (Type III) }\end{array}$ & $\mathrm{df}$ & MS & $F$ & $\mathrm{p}$ \\
\hline \multirow[t]{2}{*}{ Corrected model } & $8.380^{\mathrm{a}}$ & 3 & 2.793 & 56.932 & 0.000 \\
\hline & 133.519 & 1 & 133.519 & 2721.395 & 0.000 \\
\hline Temperature & 0.162 & 1 & 0.162 & 3.299 & 0.107 \\
\hline C. demersum & 7.761 & 1 & 7.761 & 158.194 & 0.000 \\
\hline $\begin{array}{c}\text { Temperature } \times \\
\text { C. demersum }\end{array}$ & 0.456 & 1 & 0.456 & 9.304 & 0.016 \\
\hline Error & 0.393 & 8 & 0.049 & & \\
\hline Total & 142.291 & 12 & & & \\
\hline Corrected total & 8.772 & 11 & & & \\
\hline \multicolumn{6}{|c|}{${ }^{\mathrm{a}} \mathrm{R}^{2}=0.955$ (adjusted $\mathrm{R}^{2}=0.938$ ) } \\
\hline
\end{tabular}

\section{Chlorophyll fluorescence}

$F_{\mathrm{v}} / F_{\mathrm{m}}$ and $\mathrm{ETR}_{\max }$ are important indicators of photosynthetic efficiency and activities of PSII. ETR $\mathrm{max}_{\text {ax }}$ is closely associated with carbon assimilation activity in photosynthesis. 

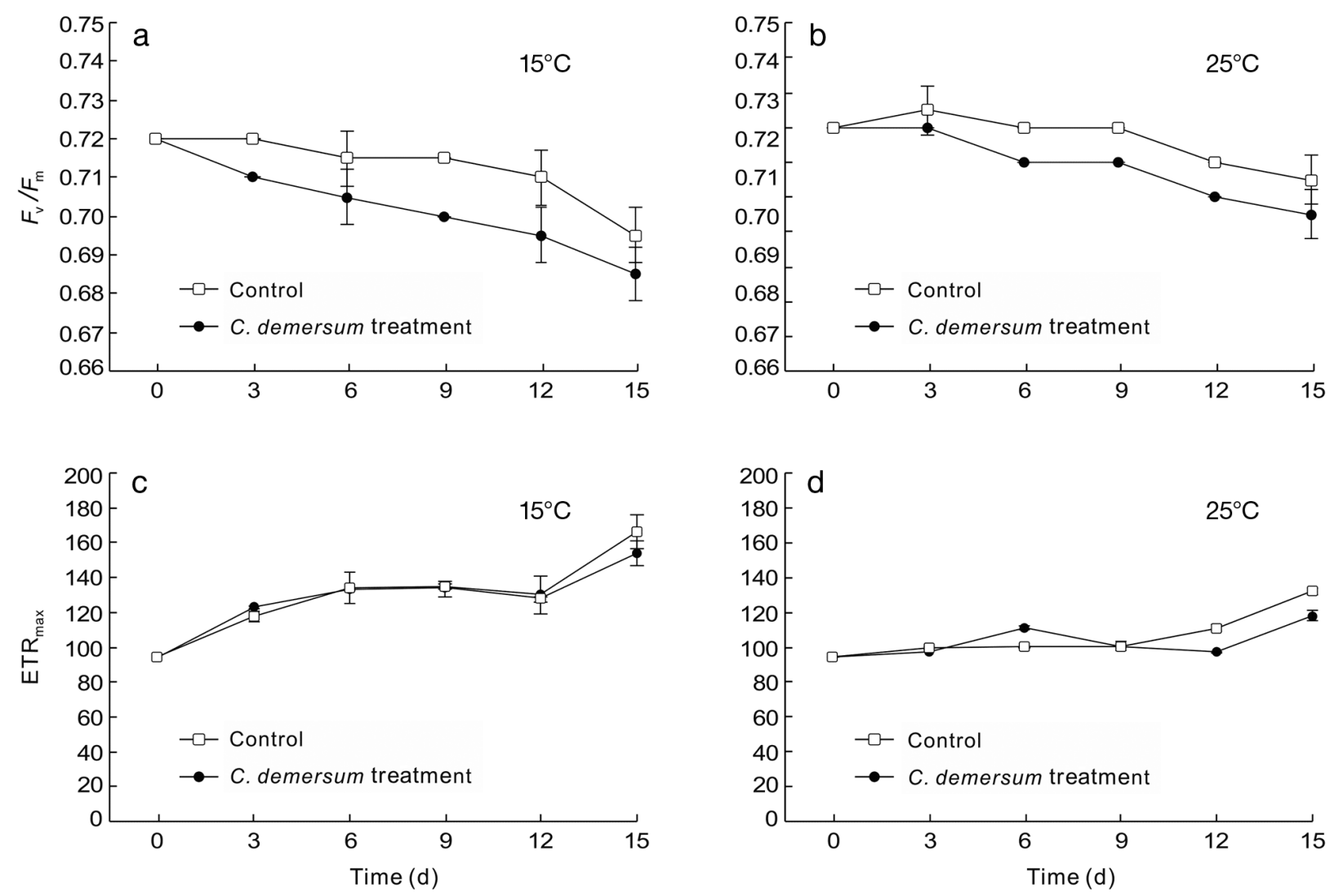

Fig. 3. Photosynthetic activities measured as $(\mathrm{a}, \mathrm{b})$ ratio of variable fluorescence to maximum fluorescence $\left(F_{\mathrm{v}} / F_{\mathrm{m}}\right)$ and $(\mathrm{c}, \mathrm{d})$ maximum electron transport rate $\left(\mathrm{ETR}_{\max }\right)$ of Scenedesmus obliquus in the absence (control) and presence of Ceratophyllum demersum at 15 and $25^{\circ} \mathrm{C}$

The $F_{\mathrm{v}} / F_{\mathrm{m}}$ of Scenedesmus obliquus in the control and Ceratophyllum demersum treatment ranged approximately from 0.67 to 0.73 (Fig. 3). The presence of $C$. demersum distinctly enhanced the $F_{\mathrm{v}} / F_{\mathrm{m}}$ and $\mathrm{ETR}_{\max }$ of $S$. obliquus at both 15 and $25^{\circ} \mathrm{C}$ relative to the control (Fig. 3).

Two-way ANOVA revealed that Ceratophyllum demersum presence $(\mathrm{p}<0.01)$ and temperature $(\mathrm{p}<$ $0.01)$ exerted significant effects on the photosynthetic activities of Scenedesmus obliquus. However, the effect of the interaction of these 2 factors was not significant $(p>0.05)$ (Tables $4 \& 5)$.

\section{Proportion of Scenedesmus obliquus unicells and 4-celled coenobia}

All cultures demonstrated obvious inconsistent fluctuations between the ratio of 4 -celled coenobia and unicells: as the proportion of one decreased, the other increased (Fig. 4).

The morphology of Scenedesmus obliquus changed drastically in the control populations at both 15 and
Table 4. Between-subject effects on the dependent variable, the ratio of variable fluorescence to maximum fluorescence $\left(F_{\mathrm{v}} / F_{\mathrm{m}}\right)$ of Scenedesmus obliquus. $C$. demersum $=$ presence of Ceratophyllum demersum

\begin{tabular}{|lcccrc|}
\hline Source & $\begin{array}{c}\text { SS } \\
\text { (Type III) }\end{array}$ & df & MS & \multicolumn{1}{c|}{$F$} & $\mathrm{p}$ \\
& & & & \\
\hline Corrected model & $0.001^{\mathrm{a}}$ & 3 & 0.000 & 8.000 & 0.009 \\
& 5.796 & 1 & 5.796 & 231852.000 & 0.000 \\
Temperature & 0.000 & 1 & 0.000 & 12.000 & 0.009 \\
C. demersum & 0.000 & 1 & 0.000 & 12.000 & 0.009 \\
Temperature $\times$ & 0.000 & 1 & 0.000 & 0.000 & 1.000 \\
C. demersum & & & & & \\
Error & 0.000 & 8 & $2.500 \times 10^{-5}$ & & \\
Total & 5.797 & 12 & & & \\
Corrected total & 0.001 & 11 & & & \\
${ }^{\text {a }}{ }^{2}=0.750$ (adjusted $\left.\mathrm{R}^{2}=0.656\right)$ \\
\hline
\end{tabular}

$25^{\circ} \mathrm{C}$. During the first $3 \mathrm{~d}$, the number of 4 -celled coenobia decreased and unicells developed, followed by a short-time recovery of colony abundance. From the ninth day onwards, the 4-celled colony gradually decreased and unicells increased. At the 
Table 5. Between-subject effects on the dependent variable, maximum electron transport rate $\left(\right.$ ETR $\left._{\max }\right)$ of Scenedesmus obliquus. C. demersum = presence of Ceratophyllum demersum

\begin{tabular}{|c|c|c|c|c|c|}
\hline Source & $\begin{array}{c}\text { SS } \\
\text { (Type III) }\end{array}$ & df & MS & $F$ & $\mathrm{p}$ \\
\hline \multirow[t]{2}{*}{ Corrected model } & $4130.871^{\mathrm{a}}$ & 3 & 1376.957 & 71.190 & 0.000 \\
\hline & 243974.342 & 1 & 243974.342 & 12613.790 & 0.000 \\
\hline Temperature & 3627.902 & 1 & 3627.902 & 187.567 & 0.000 \\
\hline C. demersum & 501.167 & 1 & 501.167 & 25.911 & 0.001 \\
\hline $\begin{array}{l}\text { Temperature } \times \\
\text { C. demersum }\end{array}$ & 1.802 & 1 & 1.802 & 0.093 & 0.768 \\
\hline Error & 154.735 & 8 & 19.342 & & \\
\hline Total & 248259.948 & 12 & & & \\
\hline Corrected total & 4285.606 & 11 & & & \\
\hline \multicolumn{6}{|c|}{${ }^{\mathrm{a}} \mathrm{R}^{2}=0.964$ (adjusted $\mathrm{R}^{2}=0.950$ ) } \\
\hline
\end{tabular}

the short-term lag phase during the first 3 d. In contrast to the 4-celled coenobia, the ratio of unicells decreased (down to 7 and $5 \%$ at 15 and $25^{\circ} \mathrm{C}$, respectively) from the third day onwards. However, the population composition seemed to stabilise during the subsequent cultivation periods (Fig. 4).

Two-way ANOVA was performed on the mean ratio per ecomorph (single cell and 4-celled coenobia) at the end of the experiments to compare the populations. Results showed that Ceratophyllum demersum presence ( $\mathrm{p}<0.01)$ and temperature $(\mathrm{p}<0.01)$, as well as the interaction between the 2 factors ( $p<0.01$ ), exerted significant effects on the proportion of unicells and 4-celled coenobia (Tables 6 \& 7).

\section{Sedimentation}

The sedimentation rate from the water column of Scenedesmus obliquus in the control and the Cerato-
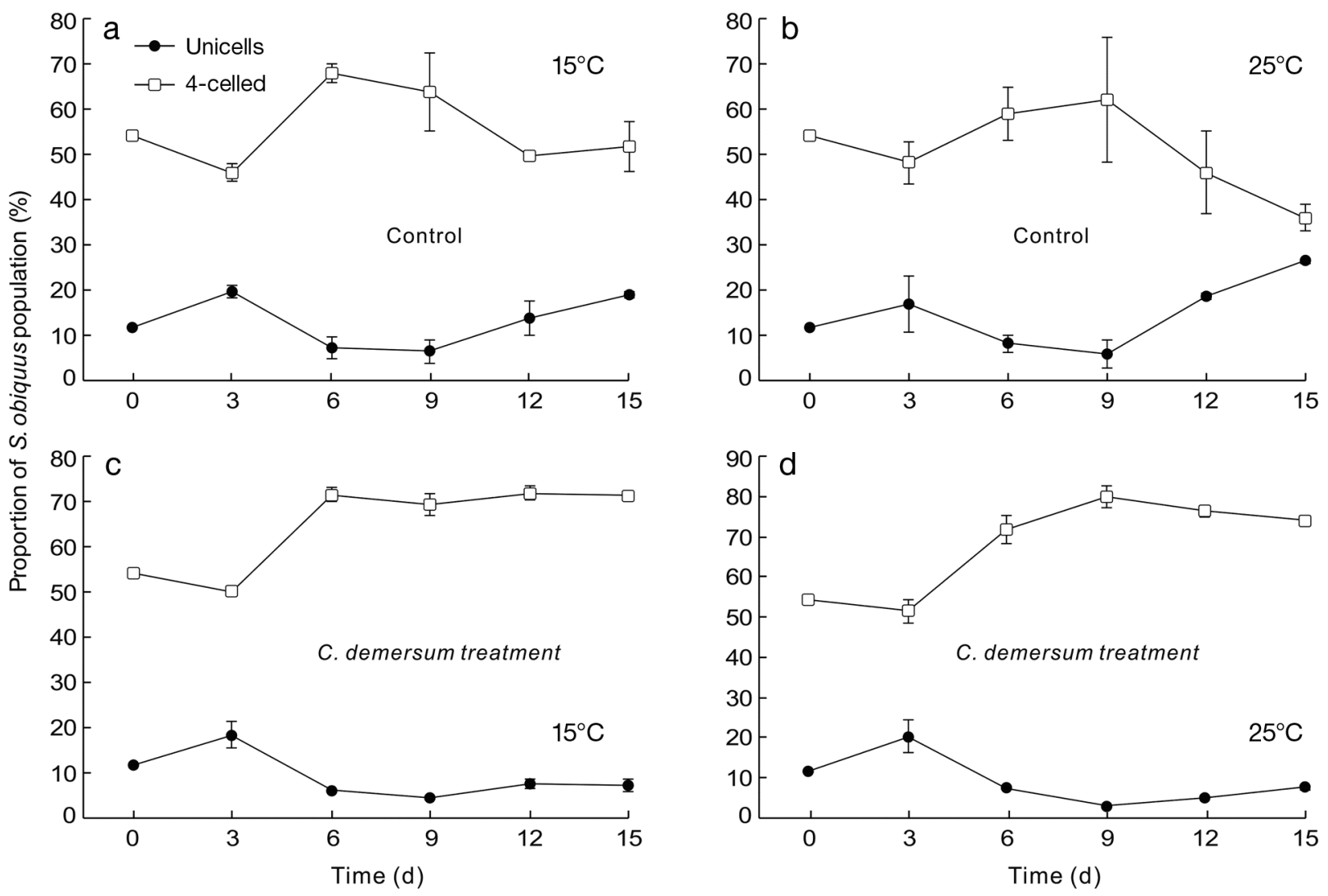

Fig. 4. Different ecomorph proportions of Scenedesmus obliquus in the $(\mathrm{a}, \mathrm{b})$ absence or $(\mathrm{c}, \mathrm{d})$ presence of Ceratophyllum demersum at 15 and $25^{\circ} \mathrm{C}$ 
Table 6. Between-subject effects on the dependent variable, proportion of unicells in Scenedesmus obliquus. C. demersum = presence of Ceratophyllum demersum

\begin{tabular}{|lrcrrr|}
\hline Source & SS & df & \multicolumn{1}{c}{ MS } & \multicolumn{1}{c|}{$F$} & $\mathrm{p}$ \\
& (Type III) & & & & \\
\hline Corrected model & $890.149^{\mathrm{a}}$ & 3 & 296.716 & 184.888 & 0.000 \\
& 2488.759 & 1 & 2488.759 & 1550.778 & 0.000 \\
Temperature & 41.232 & 1 & 41.232 & 25.692 & 0.001 \\
C. demersum & 796.380 & 1 & 796.380 & 496.235 & 0.000 \\
Temperature $\times$ & 52.537 & 1 & 52.537 & 32.737 & 0.000 \\
$\quad$ C. demersum & & & & & \\
Error & 12.839 & 8 & 1.605 & & \\
Total & 3391.747 & 12 & & & \\
Corrected total & 902.988 & 11 & & & \\
${ }^{a} \mathrm{R}^{2}=0.986$ (adjusted $\mathrm{R}^{2}=0.980$ ) & & & & \\
\hline
\end{tabular}

Table 7. Between-subject effects on the dependent variable, proportion of 4-celled coenobia in Scenedesmus obliquus. C. demersum $=$ presence of Ceratophyllum demersum

\begin{tabular}{|lrrrrr|}
\hline Source & \multicolumn{1}{c}{ SS } & df & \multicolumn{1}{c|}{ MS } & \multicolumn{1}{c|}{ F } & $\mathrm{p}$ \\
& (Type III) & & & & \\
\hline Corrected model & $3315.539^{\mathrm{a}}$ & 3 & 1105.180 & 308.823 & 0.000 \\
& 40805.104 & 1 & 40805.104 & 11402.271 & 0.000 \\
Temperature & 57.235 & 1 & 57.235 & 15.993 & 0.004 \\
C. demersum & 2986.800 & 1 & 2986.800 & 834.609 & 0.000 \\
Temperature $\times$ & 271.504 & 1 & 271.504 & 75.867 & 0.000 \\
$\quad$ C. demersum & & & & & \\
Error & 28.629 & 8 & 3.579 & & \\
Total & 44149.272 & 12 & & & \\
Corrected total & 3344.168 & 11 & & & \\
a ${ }^{2}=0.991$ (adjusted $\mathrm{R}^{2}=0.988$ ) & & & & \\
\hline
\end{tabular}

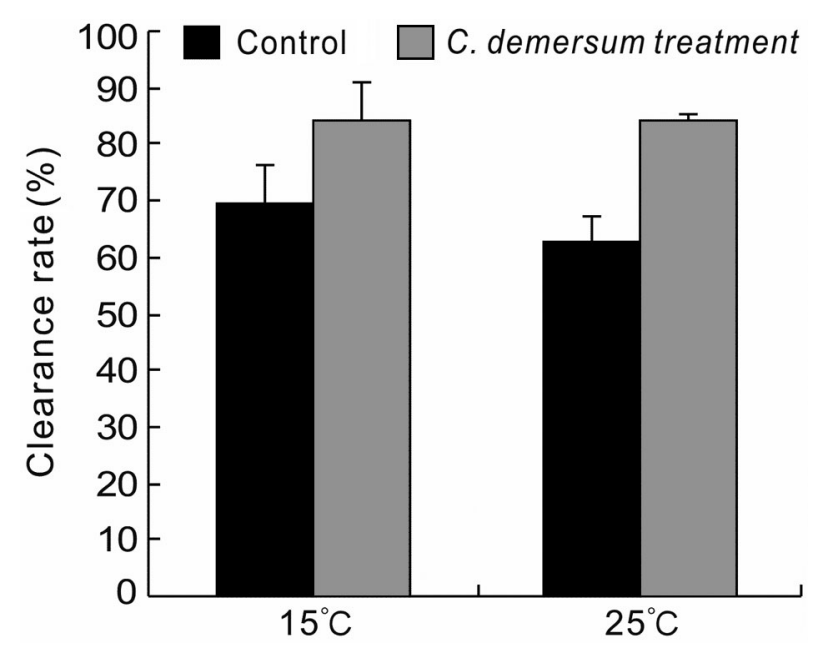

Fig. 5. Sedimentation rate of Scenedesmus obliquus biomass in the absence (control) or presence of Ceratophyllum demersum at 15 and $25^{\circ} \mathrm{C}$ phyllum demersum treatment was calculated and analysed at the end of the experiments (Fig. 5). Results showed that the sedimentation rate was significantly increased by the $C$. demersum treatment (p < 0.01) at both 15 and $25^{\circ} \mathrm{C}$ (Fig. 5, Table 8).

\section{DISCUSSION}

Scenedesmus spp. are extremely phenotypically plastic under changing environmental conditions. Algae can be either unicellular or colonial with 2-, 4- or 8celled coenobia depending on environmental conditions (Trainor \& Egan 1991). Having different ecomorphs is considered one of the adaptation strategies of Scenedesmus spp. to diversified environments. Hessen \& Van Donk (1993) discovered that the coenobia of Scenedesmus subspicatus are induced by chemical cues released by zooplankton. Their study is the first report on the colony induction of Scenedesmus by biological interaction although there have been numerous studies on grazer-induced colony formation (Lampert et al. 1994, Lürling \& Van Donk 1996, Lürling 1999, 2003, Von Elert \& Franck 1999, Ha et al. 2004, Verschoor et al. 2004, Yang \& Li 2007). It is more difficult for grazers to predate on colonial than on single cell Scenedesmus, but it is easier for the colonial formations to sediment in bottom waters under natural conditions (Lürling et al. 1997).

The present study demonstrated another type of colony induction caused by a biological interaction (between phototrophic organisms). A larger number of 4-celled coenobia were observed in the presence of submerged Ceratophyllum demersum. This finding is in agreement with Mulderij et al. (2005b) and Leflaive et al. (2008), who made similar observations for Stratiotes aloides and Uronema confervicolum (Ulotrichales). The present study has provided additional information on the colony induction of Scenedesmus spp. by phototrophic organisms. Similar to colony induction by grazers (Lürling \& Van Donk 2000, Verschoor et al. 2004), the present study shows that colony induction by submerged plants (macrophyte-phytoplankton interaction) also increases the algae's sedimentation rates to bottom waters (Fig. 5). Insufficient light in the bottom waters 
Table 8. Tests of between-subject effects on the dependent variable, sedimentation rate (clearance proportion) of Scenedesmus obliquus. C. demersum $=$ presence of Ceratophyllum demersum

\begin{tabular}{|lccrrr|}
\hline Source & $\begin{array}{c}\text { SS } \\
\text { (Type III) }\end{array}$ & df & \multicolumn{1}{c}{ MS } & \multicolumn{1}{c|}{$F$} & $\mathrm{p}$ \\
\hline Corrected model & $1412.382^{\mathrm{a}}$ & 3 & 470.794 & 16.308 & 0.000 \\
& 90499.152 & 1 & 90499.152 & 3134.787 & 0.000 \\
Temperature & 52.474 & 1 & 52.474 & 1.818 & 0.202 \\
C. demersum & 1313.375 & 1 & 1313.375 & 45.494 & 0.000 \\
Temperature $\times$ & 46.533 & 1 & 46.533 & 1.612 & 0.228 \\
$\quad$ C. demersum & & & & & \\
Error & 346.432 & 12 & 28.869 & & \\
Total & 92257.967 & 16 & & & \\
Corrected total & 1758.814 & 15 & & & \\
a ${ }^{2}=0.803$ (adjusted $\mathrm{R}^{2}=0.754$ ) & & & & & \\
\hline
\end{tabular}

suppresses algal growth (Lürling \& Van Donk 2000), thereby liberating macrophytes from competition for light and/or nutrients with algae. This mechanism provides competitive advantages for submerged plants.

In the present study, Ceratophyllum demersum treatment $\left(3 \mathrm{~g} \mathrm{FW} \mathrm{l}^{-1}\right)$ increased the growth rate, pigments and photosynthetic activities of Scenedesmus obliquus. This result is in agreement with the study by Chen (1999), which indicated that a low concentration $\left(<4 \mathrm{~g} \mathrm{FW}^{-1}\right)$ of $C$. demersum promotes the growth of $S$. obliquus, but a high concentration $(>4 \mathrm{~g}$ $\mathrm{FW} \mathrm{l}^{-1}$ ) of the plant inhibits algal growth. However, our result is not consistent with the study by Wu et al. (2011), which indicated that the growth of S. obliquus co-cultured with $C$. demersum is inhibited. The contradicting results may be due to the different C. demersum concentrations used. The allelopathic effects of submerged plants on algae depend on the initial biomass of the submerged plant and initial algal density (Körner \& Nicklisch 2002, Wu et al. 2007).

The mechanism of the colony induction of Scenedesmus spp. by submerged plants is also of interest. The colony induction by Stratiotes aloides (Mulderij et al. 2005b) is considered an allelopathic effect. In the present study, the Ceratophyllum demersum culture filtrates experiment was also conducted according to $\mathrm{Wu}$ et al. (2007) to eliminate the effects of nutrients and light in the co-culture experiment. $C$. demersum ( $3 \mathrm{~g} \mathrm{FW} \mathrm{l}^{-1}$ ) was cultured for $10 \mathrm{~d}$ for the experiments, and the initial optical density of Scenedesmus obliquus was set at $0.1\left(\mathrm{OD}_{680}=0.1\right)$, which is the same as in the co-culture experiments. The effects of $C$. demersum culture filtrates on the photosynthetic activities $\left(F_{\mathrm{v}} / F_{\mathrm{m} i}\right.$ ETR $\left._{\max }\right)$, photosynthetic pigments (chl $a_{i}$ carotenoid) and the growth rate of Scenedesmus obliquus were similar to those of the co-culture (the results are not presented in this paper). However, colony induction was not obvious in the $C$. demersum culture filtrates, which may be due to the low concentration of the colony-inducing compounds in the culture filtrates (Leflaive et al. 2008). Similar to Uronema confervicolum, the colony-inducing and active effects of $C$. demersum filtrates may be linked to different compounds (Leflaive et al. 2008). Another hypothesis is that the active compounds that induce colony formation are only secreted when Scenedesmus obliquus is co-cultured with $C$. demersum. To date, the active compounds released by submerged plants on the ecomorphs of Scenedesmus spp. have not been studied. However, kairomones, which are aliphatic sulphates released by Daphnia, were found to cause colony formation of Scenedesmus (Yasumoto et al. 2005). Thus, further study must be conducted to determine whether the aliphatic sulphates are similar to the active compounds released by C. demersum, which caused a morphological shift in Scenedesmus obliquus.

The co-culture experiments also indicated that the effect of Ceratophyllum demersum on Scenedesmus obliquus is related to cultivation temperature. Metabolic processes have been reported to be profoundly affected by temperature (Rhee \& Gotham 1981, Davidson 1991). Low temperature can increase the amount of carbohydrates per cell, but decrease the amounts of protein and lipids (Aaronson 1973). In the present study, C. demersum treatment at $25^{\circ} \mathrm{C}$ exerted greater influence on 4-celled colony formation, the proportion of which increased from 36 to $76 \%$, whereas the proportion of 4 -celled colony formation only increased from 51 to $71 \%$ at $15^{\circ} \mathrm{C}$ (Fig. 4). The relatively weaker response at the lower temperature may be due to the relatively fewer active compounds released.

The present study provides insight into allelopathic-induced colony formation of Scenedesmus spp. by submerged plants. The aliphatic sulphatelike substances released by the plants may be the active compounds that caused the morphological shift in S. obliquus. In addition, temperature possibly contributes to the substance release, thereby affecting the morphological shift in S. obliquus. However, this is only a hypothesis. Further investigation of the chemical compounds that caused the morphological shift in $S$. obliquus is urgently needed. 
Acknowledgements. We thank the editors and the 3 anonymous reviewers for their constructive comments and suggestions, which were of great help in improving the manuscript.

\section{LITERATURE CITED}

Aaronson S (1973) Effect of incubation temperature on the macromolecular and lipid content of the phytoflagellate Ochromonas danica. J Phycol 9:111-113

Anthoni U, Christophersen C, Ogard Madsen S, WiumAnderson S, Jacobsen N (1980) Biological active sulphur compounds from the green algae Chara globularis. Phytochemistry 19:1228-1229

Bienfang PK (1981) SETCOL - a technically simple and reliable method for measuring phytoplankton sinking. Can J Fish Aquat Sci 38:1289-1294

Blindow I (1992) Decline of charophytes during eutrophication: comparison with angiosperms. Freshw Biol 28:9-14

Chen DH (1999) Studies on interspecies competition and biological process of formation of cyanobacterial blooms. $\mathrm{PhD}$ thesis, Institute of Hydrobiologia, Chinese Academic of Sciences, Wuhan

Davidson IR (1991) Environmental effects on algal photosynthesis: temperature. J Phycol 8:138-143

Erhard D, Gross EM (2006) Allelopathic activity of Elodea Canadensis and Elodea nuttallii against epiphytes and phytoplankton. Aquat Bot 85:203-211

Gross EM (2003) Allelopathy of aquatic autotrophs. Crit Rev Plant Sci 22:313-339

Gross EM, Meyer H, Schilling G (1996) Release and ecological impact of algicidal hydrolysable polyphenols in Myriophyllum spicatum. Phytochemistry 41:133-138

Ha K, Jang MH, Takamura N (2004) Colony formation in planktonic algae induced by zooplankton culture media filtrate. J Freshw Ecol 19:9-16

Hessen DO, Van Donk E (1993) Morphological changes in Scenedesmus induced by substances released from Daphnia. Arch Hydrobiol 127:129-140

Jasser I (1994) Influences of Ceratophyllum demersum on phytoplankton community in experimental conditions. Verh Int Verein Limnol 25:2291-2295

Jeppesen E, Scondergaard M, Sondergaard M, Christoffersen K (1997) The structuring role of submerged macrophytes in lakes. Ecol Stud 131. Springer, New York, NY

Körner S, Nicklisch A (2002) Allelopathic growth inhibition of selected phytoplankton species by submerged macrophytes. J Phycol 38:862-871

Lampert W, Rothhaupt KO, Von Elert E (1994) Chemical induction of colony formation in a green alga (Scenedesmus acutus) by grazers (Daphnia). Limnol Oceanogr 39:1543-1550

Leflaive J, Lacroix G, Nicaise Y, Ten Hage L (2008) Colony induction and growth inhibition in Desmodesmus quadrispina (Chlorococcales) by allelochemicals released from the filamentous alga Uronema confervicolum (Ulotrichales). Environ Microbiol 10:1536-1546

Lichtenthaler HK, Buschmann C (2001) Current protocols in food analytical chemistry. Chlorophylls and carotenoids: measurement and characterization by UV-VIS spectroscopy. Wiley, New York, NY, p F4.3.1-F4.3.8

Lürling M (1999) Grazer-induced coenobial formation in clonal cultures of Scenedesmus obliquus (Chlorococcales, Chlorophyceae). J Phycol 35:19-23
Lürling M (2003) The effect of substances from different zooplankton species and fish on the induction of defensive morphology in the green alga Scenedesmus obiquus. J Plankton Res 25:979-989

Lürling M, Van Donk E (1996) Zooplankton-induced unicellcolony transformation in Scenedesmus acutus and its effect on growth of herbivore Daphnia. Oecologia 108: 432-437

Lürling M, Van Donk E (1999) Grazer-induced colony formation in Scenedesmus acutus (Chlorophyceae): ecomorph expression at different temperatures. J Phycol 35: 1120-1126

Lürling M, Van Donk E (2000) Grazer-induced colony formation in Scenedesmus: are there costs to being colonial? Oikos 88:111-118

Lürling M, De Lange HJ, Van Donk E (1997) Changes in food quality of the green algae Scenedesmus induced by Daphnia infochemicals: biochemical composition and morphology. Freshw Biol 38:619-628

Lürling M, Geest GV, Scheffer M (2006) Importance of nutrient competition and allelopathic effects in suppression of the green alga Scenedesmus obliquus by the macrophytes Chara, Elodea and Myriophyllum. Hydrobiologia 556:209-220

Moss B, Madgwick J, Phillips G (1996) A guide to the restoration of nutrient-enriched shallow lakes. Broads Authority, Environment Agency and EU Life Programme, Norwich

Mulderij G, Van Donk E, Roelofs JGM (2003) Differential sensitivity of green algae to allelopathic substances from Chara. Hydrobiologia 491:261-271

Mulderij G, Mooij WM, Smolders AJP, Van Donk E (2005a) Allelopathic inhibition of phytoplankton by exudates from Stratiotes aloides. Aquat Bot 82:284-296

Mulderij G, Van Donk E, Roelofs JGM (2005b) Allelopathic growth inhibition and colony formation of the green alga Scenedesmus obliquus by the aquatic macrophate Stratiotes aloides. Aquat Ecol 39:11-21

Phillips GL, Eminson D, Moss B (1978) A mechanism to account for macrophyte decline in progressively eutrophicated freshwaters. Aquat Bot 4:103-126

Rhee GY, Gotham IJ (1981) The effect of environmental factors on phytoplankton growth: temperature and the interaction of temperature with nutrient limitation. Limnol Oceanogr 26:635-648

> Rippka R, Deruelles J, Waterbury J, Herdman M, Stanier R (1979) Generic assignments, strain histories and properties of pure cultures of cyanobacteria. J Gen Microbiol 111:1-61

Shubert LE, Trainor FR (1974) Control of the unicell stage with phosphorus. Br Phycol J 9:1-7

Siver PA, Trainor FR (1981) Morphological control and physiology of Scenedesmus strain 170. Phycologia 20:1-11

Trainor FR (1992) Cyclomorphosis in Scenedesmus communis Hegew. Ecomorph expression at low temperature. $\mathrm{Br}$ Phycol J 27:75-81

Trainor FR (1993) Cyclomorphosis in Scenedesmus subspicatus (Chlorococcales, Chlorophyta): stimulation of colony development at low temperature. Phycologia 32: 429-433

> Trainor FR, Egan PF (1991) Discovering the various ecomorphs of Scenedesmus: the end of a taxonomic era. Arch Protistenkd 139:125-132

Verschoor AM, van der Stap I, Helmsing NR (2004) Inducible colony formation within the Scenedesmaceae: 
adaptive responses to infochemicals from two different herbivore taxa. J Phycol 40:808-814

Von Elert E, Franck A (1999) Colony formation in Scenedesmus: grazer-mediated release and chemical features of the infochemical. J Plankton Res 21:789-804

Wu ZB, Deng P, Wu XH, Luo S, Gao YN (2007) Allelopathic effects of the submerged macrophyte Potamogeton malaianus on Scenedesmus obiquus. Hydrobiologia 592:465-474

Wu S, Li XH, Yang L (2011) Experimental study on the allelopathy of two kind of submerged plants. Bioinformatics and Biomedical Engineering (iCBBE) 5th Int

Editorial responsibility: Max Tilzer,

Konstanz, Germany
Conf, Wuhan, China. IEEE Xplore, p 1-4, doi:10.1109/ icbbe.2011.5780841

Yang Z, Li JJ (2012) Effects of Daphnia-associated infochemicals on the morphology and growth of Scenedesmus obiquus and Microcystis aeruginosa. J Freshw Ecol 22:249-253

Yasumoto K, Nishigami A, Yasumoto M, Kasai F, Okada Y, Kusumi T, Ooi T (2005) Aliphatic sulfates released from Daphnia induce morphological defense of phytoplankton: isolation and synthesis of kairomones. Tetrahedron Lett 46:4765-4767

Submitted: March 14, 2013; Accepted: August 14, 2013 Proofs received from author(s): October 27, 2013 